\title{
Effects of Rumen-Protected Choline and Monensin on Milk Production and Metabolism of Periparturient Dairy Cows
}

\author{
L. C. Zahra, ${ }^{*}$ T. F. Duffield, ${ }^{\star}$ K. E. Leslie, ${ }^{\star}$ T. R. Overton,† D. Putnam, $\ddagger$ and S. J. LeBlanc ${ }^{\star 1}$ \\ *Department of Population Medicine, University of Guelph, Guelph, Ontario, Canada N1G 2W1 \\ †Department of Animal Science, Cornell University, Ithaca, NY 14853 \\ łBalchem Corporation, Slate Hill, NY 10973
}

\section{ABSTRACT}

Choline and monensin may be supplemented during the transition period with the objectives of aiding in fat metabolism and improving energy balance, respectively. The objectives of this study were to determine the effects of supplementing rumen-protected choline (RPC) and monensin in a controlled-release capsule (CRC) on metabolism, dry matter intake, milk production, and liver function in transition dairy cattle. Three weeks before expected calving, 182 Holsteins were randomly assigned to receive one of the following: a monensin CRC, $56 \mathrm{~g} / \mathrm{d}$ of RPC until $28 \mathrm{~d}$ in milk, CRC + RPC, or neither supplement (control). Blood samples were collected at enrollment, $1 \mathrm{wk}$ before calving, and in the first and second weeks after calving. Liver biopsies were obtained from multiparous cows randomly selected from each treatment group within $24 \mathrm{~h}$ and again 3 wk postpartum. Daily milk production was recorded through $60 \mathrm{~d}$ in milk. There were no interactions of the effects of RPC and CRC on any of the outcomes measured. Overall, cows that received RPC produced $1.2 \mathrm{~kg} / \mathrm{d}$ more milk in the first $60 \mathrm{~d}$ of lactation, but this effect was attributable to an increase in milk production of $4.4 \mathrm{~kg} / \mathrm{d}$ among cows with a body condition score $\geq 4$ at 3 wk before calving; fat cows that received $\mathrm{RPC}$ ate $1.1 \mathrm{~kg}$ of DM/d more from wk 3 before calving through wk 4 after calving. Monensin supplementation significantly increased serum concentrations of glucose and urea, lowered concentrations of $\beta$ hydroxybutyric acid and aspartate aminotransferase in the peripartum period, and increased liver glycogen content at $3 \mathrm{wk}$ into lactation. The metabolic effects of CRC are consistent with previous studies, and the effects on liver are novel. The mechanism by which RPC increased milk production was not revealed in this study and merits further research.

Key words: choline, monensin, transition dairy cattle, metabolism

Received January 24, 2006.

Accepted July 23, 2006.

${ }^{1}$ Corresponding author: sleblanc@ovc.uoguelph.ca

\section{INTRODUCTION}

Management and nutrition during the transition period influence milk production, the incidence of peripartum metabolic disorders, and reproductive performance. Therefore, management of cows during this critical stage is crucial for the productivity of dairy cattle (Overton and Waldron, 2004). Choline is a nutrient involved with the transport of fat from the liver, synthesized in part from methionine, and required for the synthesis of phosphatidylcholine, a phospholipid found in the membranes of very low density lipoprotein (NRC, 2001). Hence, choline deficiency in transition dairy cattle may be associated with hepatic lipidosis. In the past, choline was classified as a B vitamin; however, because it is not directly involved in enzyme systems and because it is required in gram vs. milligram amounts, it has since been described as a quasivitamin (Combs, 1992). Unprotected dietary choline is almost completely degraded in the rumen (Sharma and Erdman, 1988), such that increased choline supply to the tissues requires supplementation in a rumenprotected form. Some studies have shown that supplementing transition cows with rumen-protected choline (RPC) may increase milk yield (Erdman and Sharma, 1991; Pinotti et al., 2003). Although specific mechanisms for this effect have not been fully described, several studies point to enhanced export of fat from the liver in cows supplemented with RPC (Piepenbrink and Overton, 2003; Cooke et al., 2004); RPC supplementation may also spare methionine (Pinotti et al., 2002).

Monensin alters the flux of monovalent ions across the membranes of gram-positive bacteria, disrupting their normal function and causing them to lyse (Duffield and Bagg, 2000). When monensin is supplemented to dairy cattle it alters the bacterial populations in the rumen such that bacteria that synthesize propionic acid will be favored. In the ruminant, propionic acid is a precursor of glucose. An increase in glucose availability in turn decreases the need for fat mobilization to support milk production. Several studies have shown monensin to reduce circulating concen- 
trations of ketones, particularly BHBA, by increasing available gluconeogenic precursors (Abe et al., 1994; Duffield et al., 1998a, 2003). As a consequence of improving energy balance, monensin has also been shown to improve milk production, particularly in cows that are susceptible to ketosis (Lean et al., 1994; Beckett et al., 1998; Duffield et al., 1999).

There have been a number of studies conducted on monensin and RPC independently, but no studies to date on the possible interaction of these 2 supplements. Previous work has shown that monensin can improve energy balance and conditionally improve milk production in transition cows, whereas choline can improve liver metabolism and milk production. Therefore, given their different modes of action, it was hypothesized that administering choline in addition to monensin to transition dairy cattle may have additive or synergistic effects on milk production. The objectives of this study were to determine the effects of choline and monensin on metabolic parameters, DM intake, milk production, and milk components as well as liver triglyceride (TG) and glycogen contents in transition dairy cows.

\section{MATERIALS AND METHODS}

Between July 2002 and August 2003, a total of 182 Holstein primiparous and multiparous cows were randomly assigned to 1 of 4 treatment groups in a $2 \times 2$ factorial design 3 wk before their expected calving dates, using block randomization based on parity (multiparous and primiparous). At enrollment, cows received a placebo monensin controlled-release capsule (control), or were fed a daily premeasured topdress of $56 \mathrm{~g}$ of RPC (25\% wt/wt of choline; Reashure choline, Balchem Encapsulates, New Hampton, NY) supplying approximately $14 \mathrm{~g}$ until $28 \mathrm{~d}$ postpartum, or received a monensin controlled-release capsule (CRC; Rumensin CRC, Elanco, Guelph, ON, Canada), or both supplements (RPC + CRC). The ability of the RPC product used in this study to escape ruminal degradation has been reported to be $85 \%$ (Kung et al., 2003). The CRC devices used in this study deliver $335 \mathrm{mg} / \mathrm{d}$ of monensin sodium for $95 \mathrm{~d}$, according to the manufacturer. Animals were housed at 2 University of Guelph dairy research barns. The experiment was approved by the University's Animal Care Committee.

Cows were housed in a tie-stall barn with individually partitioned feed bunks for $3 \mathrm{wk}$ before their expected calving date and were then transferred into maternity box stalls for calving. After calving, cows were returned to the tie-stalls. At enrollment, all cows were fed a dry-cow TMR ad libitum until parturition, after which all cows were fed a lactating-cow TMR ad
Table 1. Composition and nutrient analysis of the TMR diets

\begin{tabular}{lcc}
\hline Item & Prepartum & Lactating \\
\hline DM (\%) & 53.7 & 48.9 \\
Predicted DM intake ${ }^{1}$ (kg/d) & 9.2 & 21.9 \\
Feed ingredients, \% of diet DM & & \\
Grass hay & 8.0 & 4.8 \\
Haylage & 16.1 & 22.1 \\
Corn silage & 56.8 & 34.5 \\
High-moisture corn & 8.0 & 20.0 \\
Dry cow supplement ${ }^{2}$ & 11.1 & - \\
Lactating cow supplement ${ }^{3}$ & - & 18.6 \\
Nutrient content (DM basis) & & \\
NE, Mcal/kg & 1.59 & 1.81 \\
ME, Mcal/d & 23.0 & 59.2 \\
CP, \% & 14.6 & 16.8 \\
MP, ${ }^{1}$ g/d & 810 & 2,264 \\
NDF, \% & 41.3 & 28.5 \\
Calcium, \% & 0.51 & 0.83 \\
Phosphorus, \% & 0.54 & 0.71 \\
Methionine, ${ }^{\text {g }}$ /d; predicted & 18 & 45 \\
\hline
\end{tabular}

${ }^{1}$ Calculated values from Cornell-Penn-Miner Dairy model version 3.0.7a.

${ }^{2}$ Dry cow supplement was formulated for $33.9 \%$ CP, $7.9 \%$ soluble protein, $16.5 \% \mathrm{NDF}, 2.8 \%$ crude fat, $1.8 \% \mathrm{Ca}, 1.2 \% \mathrm{P}, 1.53 \mathrm{Mcal} / \mathrm{kg}$ $\mathrm{NE}_{1}$ and $-221.38 \mathrm{mEq} / \mathrm{kg} \mathrm{DCAD}$, and contained soybean meal, canola meal, wheat shorts, wheat bran, soy hulls (ground), dicalcium phosphate, fine salt, vitamin E (50 KIU/kg), calcium carbonate, molasses, selenium 200, ruminant micro premix, Yea-Sac (Yea-Sac 1026, Alltech, Nicholasville, KY), sulfur flour, and magnesium oxide.

${ }^{3}$ Lactating cow supplement was formulated for $35.5 \% \mathrm{CP}, 7.6 \%$ soluble protein, $15.2 \% \mathrm{NDF}, 5.5 \%$ crude fat, $2.5 \% \mathrm{Ca}, 1.1 \% \mathrm{P}$ and $1.38 \mathrm{Mcal} / \mathrm{kg}$ NEL and contained: soybean meal, Hi-Pro corn gluten meal, canola meal, roasted whole soybeans, ground soy hulls, beet pulp, blood meal, calcium carbonate, dicalcium phosphate, sodium bicarbonate, herring fish meal, fine salt, golden flake, molasses, ruminant micro premix, magnesium oxide, urea, fibrozyme, sulfur flour, and Yea-Sac.

libitum (Table 1). Cows were fed a TMR twice daily (at 0500 and $1500 \mathrm{~h}$ ) and were also milked twice daily (at 0630 and $1530 \mathrm{~h}$ ). All cows were fed individually throughout the study. Placebo and monensin CRC were administered by a research technician and were individually recorded using their unique identification numbers for tracing purposes. Barn staff added the 56 $\mathrm{g}$ of premeasured RPC as a topdress on the TMR once daily for the appropriate animals from 3 wk before their expected calving date until 4 wk into lactation. The personnel who administered the treatments were not involved with measurement of the outcomes. Three times weekly, samples of both the dry-cow and lactating-cow TMR diets were taken and frozen until samples were ready to be dried. Similarly, orts samples were also taken 3 times weekly on days that feed samples were not taken. Within fresh feed and orts samples, daily TMR samples were pooled to determine weekly averages of DM content. Orts however, were weighted based on feed intakes recorded by the barn staff before pooling the weighted samples to obtain weekly DM averages. Feed and orts samples were col- 
lected from 3 wk before expected calving dates until 4 wk into lactation. All samples were dried at $60^{\circ} \mathrm{C}$ for $72 \mathrm{~h}$, and then weighed to determine moisture loss. Dry matter averages for feed and orts were used to calculate individual daily DMI. Ration ingredient lists, and feed ingredient analyses were obtained monthly throughout the trial. The nutrient content of corn silage, haylage, and hay for the milking and dry-cow TMR were analyzed monthly by a commercial laboratory (Agri-Food Laboratories, Guelph, Ontario, Canada). Rations were then adjusted accordingly to maintain consistent nutrient levels. Summary ration data are reported in Table 1 . The lactating cow ration was formulated for a second-lactation cow, with a BCS of 3.0 , producing $38 \mathrm{~kg}$ of milk/d at 120 DIM with $3.7 \%$ milk fat and $3.5 \%$ protein.

At enrollment, body condition was scored on a scale from 1 to 5 , using increments of 0.25 , as described by Edmonson et al. (1989). The first of 4 blood samples was also collected at this time $(-21 \pm 7 \mathrm{~d})$ from the coccygeal vein. Blood was collected using $10-\mathrm{mL}$ glass vacuum tubes without anticoagulant (Becton-Dickinson Vacutainer Systems, Franklin Lakes, NJ). Blood sampling was repeated approximately $1 \mathrm{wk}(-7 \pm 3 \mathrm{~d})$ before the expected calving date, as well as in the first $(+7 \pm 2 \mathrm{~d})$ and second weeks $(+14 \pm 3 \mathrm{~d})$ postpartum. All blood samples were taken between 0800 and 1100 h. Blood samples were permitted to clot, after which they were centrifuged, and the serum separated and stored at $-20^{\circ} \mathrm{C}$ until analysis. Sera were submitted to the University of Guelph Animal Health Laboratory for measurement of concentrations of BHBA, glucose, cholesterol, NEFA, urea, and aspartate aminotransferase (AST) using a Hitachi 911 biochemistry analyzer (Boehringer Mannheim, Mannheim, Germany). At 2 wk into lactation, animals were assigned a second BCS. Health records were obtained on each animal throughout the trial.

Daily milk weights were obtained until 60 DIM from on-farm records. Milk fat and protein percentages were obtained from the first 2 DHI tests. The first DHI test occurred at $21 \pm 10 \mathrm{DIM}$, and the second DHI test at $50 \pm 9$ DIM. Genetic indices for milk production were obtained for each animal from on-farm records. For multiparous cows, genetic indices for milk production were obtained from the lactation preceding enrollment on this trial. Estimated genetic indices for primiparous animals were obtained from pedigrees that were based on sire and dam genetic indices for milk production. All genetic indices were calculated by the Canadian Dairy Network.

Within $24 \mathrm{~h}$ postpartum, and in the third week of lactation, liver biopsies were collected from multiparous animals using the percutaneous trochar biopsy method as described by Veenhuizen et al. (1991). Liver tissue was cleaned with sterile gauze upon collection and placed into labeled plastic tissue collection tubes. Samples were placed on ice for transportation to the University of Guelph, after which they were stored at $-80^{\circ} \mathrm{C}$ until the samples were ready to be analyzed. Liver samples were collected from October 2002 until August 2003. In January 2004, all liver samples were transported on frozen carbon dioxide to the Cornell University Animal Metabolism Laboratory in Ithaca, New York. There, trained laboratory technicians determined liver glycogen contents according to the procedures described by Lo et al. (1970), and liver TG contents were determined using the procedures outlined by Hara and Radin (1978). Samples were analyzed in duplicate and mean values were used for analysis.

\section{Statistical Analysis}

Statistical analyses were performed using SAS (Version 8; SAS Institute, Inc., Cary, NC). All dependent variables and their residuals were evaluated for normality using the GLM procedure in SAS by inspection of standardized residuals plotted against the predicted residuals. Standardized residuals were also inspected graphically to assess fit to a normal distribution. Raw data for BHBA, NEFA, AST, urea, milk protein, and liver TG were transformed to their natural logarithm to achieve a normal distribution for analysis. All transformed data were back-transformed for reporting least squares means.

Each metabolite was considered as an outcome in separate models over the whole experimental period. Multivariable linear regression analyses of the serum metabolites, DMI, milk production, and milk components were performed using the repeated measures approach with the MIXED model procedure in SAS. Repeated measures were accounted for with an autoregressive correlation structure. For serum metabolites, data were also analyzed using a spatial power correlation structure in SAS because of the unequal spacing between the first and second sampling periods. The results for metabolites were virtually identical between the covariate structures; therefore, for consistency the results with an autoregressive correlation structure are reported. Linear regression analyses of liver TG and glycogen contents were performed using PROC MIXED for each biopsy sample separately. Although liver TG and glycogen contents were potentially confounded with the effects of treatment, the values from the first biopsy were examined as covariates in the respective second biopsy models. Analysis was performed by a backward stepwise elimination 
Table 2. Descriptive data (mean and SD) on metabolites in serum by main effects for each sampling period ${ }^{1}$

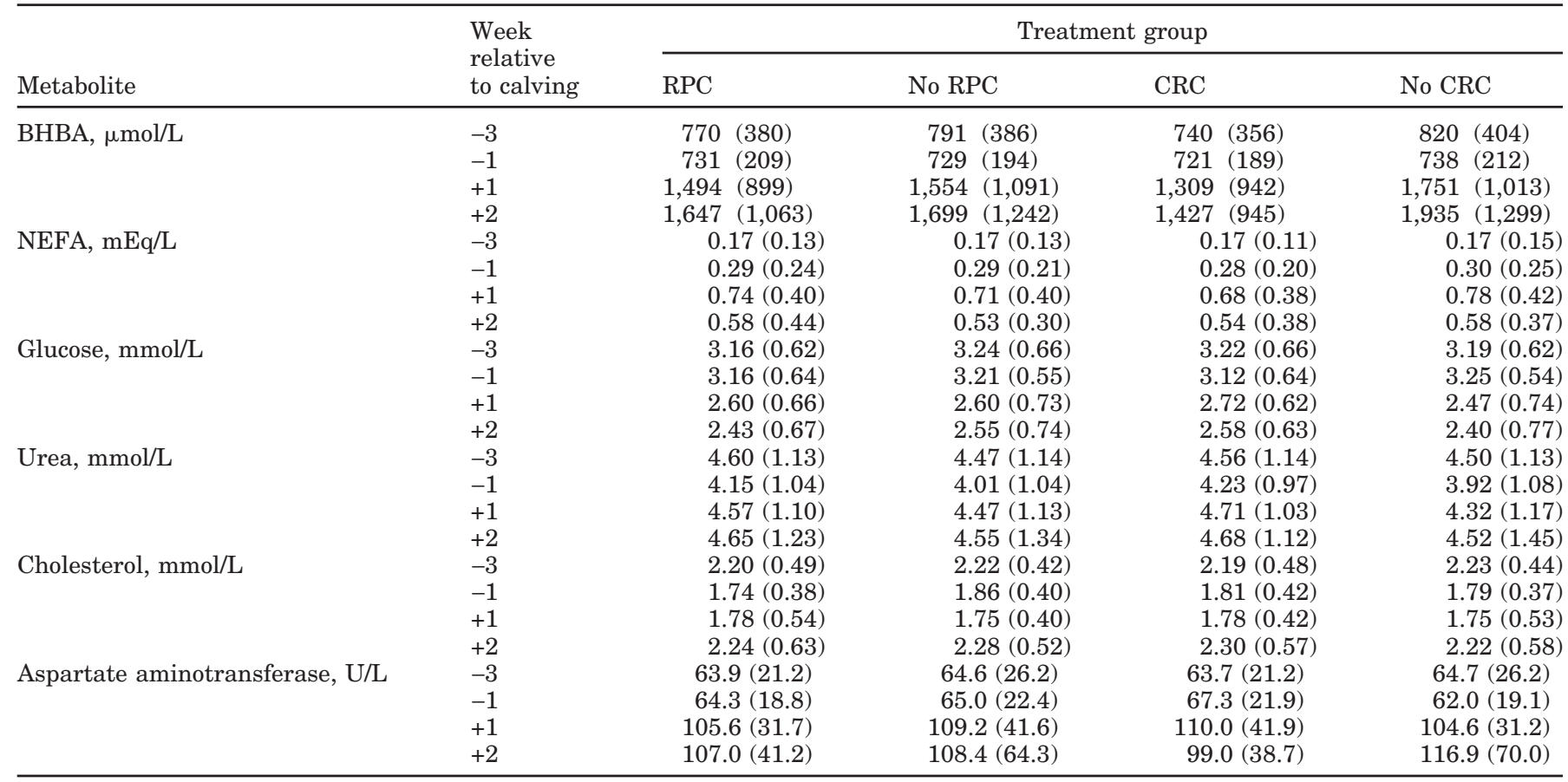

${ }^{1}$ Cattle received $56 \mathrm{~g} / \mathrm{d}$ rumen-protected choline (RPC) from 3 wk prepartum through 28 DIM or a monensin controlled-release capsule (CRC) 3 wk prepartum.

process. In addition to the main effects of treatment, the covariates calving season, parity, BCS at enrollment, and barn were offered to each model. Variables were left in the model based on a significance of $P \leq$ 0.10 . The interactions between treatment and each significant covariate within the final models were tested. In particular, based on preliminary analyses, and based on the hypothesized mechanism of action of RPC as well as previous reports of conditional effects of CRC in fat cows (Duffield et al., 1999), the interactions of treatment with fat condition $(\mathrm{BCS} \geq 4.0$ ) were examined. For each linear regression model, the main effects of RPC and CRC as well as their interaction were tested. If there was no significant interaction of RPC and CRC on the outcome, data were pooled to test for the main effects of either RPC or CRC supplementation. All covariates were tested against the main effect of treatment to determine whether they were evenly distributed among treatment groups using generalized linear modeling.

\section{RESULTS}

A total of 48 animals were in the control group, 43 received the RPC treatment, 45 received monensin $\mathrm{CRC}$, and 46 animals received both $\mathrm{RPC}$ and monensin CRC. There were 65 primiparous and 117 multiparous animals. At the time of enrollment, $10 \%$ of the cattle had BCS $\leq 3.0,68 \%$ had BCS between 3.25 and 3.75, and $22 \%$ had BCS $\geq 4.0$. There were no significant differences in the distribution of initial BCS, season of calving, parity, or barn among the treatment groups. There were no significant differences between the treatment groups in the incidences of peripartum clinical diseases.

\section{Metabolites in Blood}

Table 2 presents summary data on metabolites in serum. There were no significant interactions $(P>0.2)$ of the effects of RPC and CRC treatment on any blood metabolite concentrations; therefore, the separate main effects of RPC and CRC were evaluated. Supplementation with RPC lowered serum cholesterol concentrations, whereas CRC affected the serum concentrations of BHBA, glucose, AST, and urea. There were no significant effects of RPC or CRC on serum NEFA concentrations. For all metabolites, $\mathrm{RPC} \times \mathrm{BCS}$ and $\mathrm{CRC} \times \mathrm{BCS}$ interactions were not significant.

For serum cholesterol concentrations, there was a tendency $(P=0.07)$ for an interaction of RPC supplementation and time; therefore, the model for cholesterol was stratified by week. Animals that received RPC supplementation had significantly lower serum concentrations of cholesterol $(1.73$ vs. $1.85 \mathrm{mmol} / \mathrm{L}$, $P<0.05)$ in the week before calving compared with 


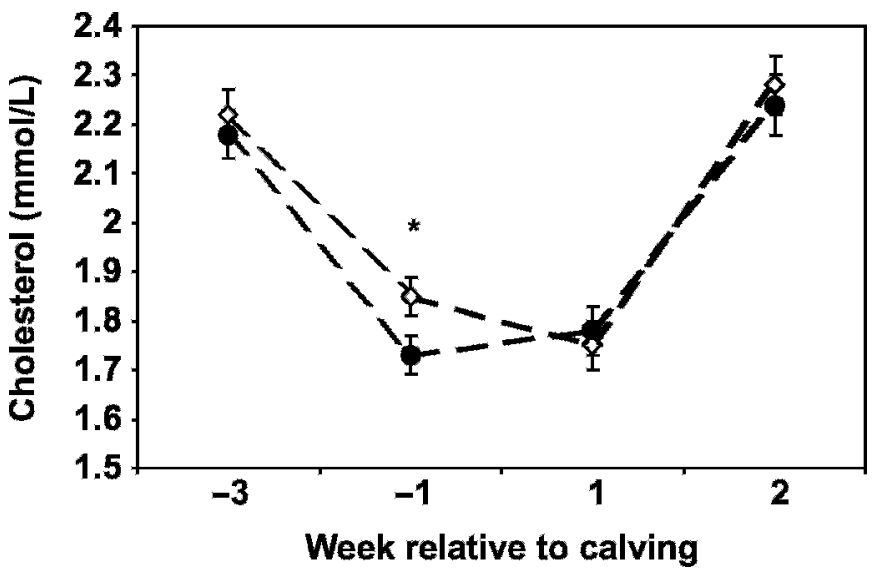

Figure 1. Least squares means $( \pm \mathrm{SE})$ of serum cholesterol concentrations in animals supplemented with rumen-protected choline $(\mathrm{RPC}, \bullet)$ or not supplemented with RPC $(\diamond)$, adjusting for parity. A significant difference $(P \leq 0.05)$ was observed in the week before calving.

animals that did not receive RPC (Figure 1). There was no effect of RPC on other metabolites.

There were significant CRC by time interactions for BHBA, glucose, and AST; therefore, these models were stratified by week. Animals that received CRC had significantly lower BHBA concentrations and higher glucose concentrations in wk 1 and 2 postpartum than animals that did not receive CRC (Figures 2 and 3 ). In the week before calving, animals that received a CRC had significantly higher serum concentrations of AST, followed by a significant reduction in concentration of AST in the second week postcalving (Figure 4). Across the experimental period, animals that received a CRC had significantly higher serum concentrations

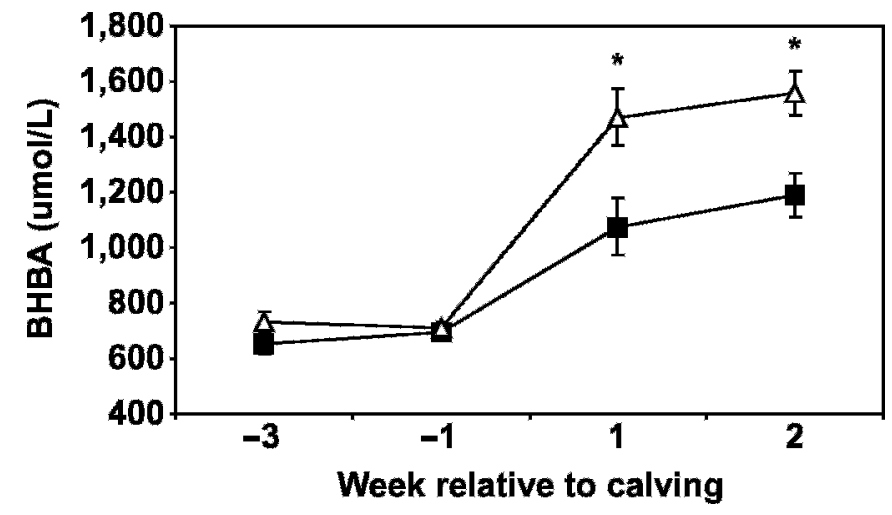

Figure 2. Least squares means $( \pm \mathrm{SE})$ of serum BHBA concentrations in animals receiving a monensin controlled-release capsule $(\mathrm{CRC}, \mathbf{\square})$ or not receiving a CRC $(\triangle)$, adjusting for parity, BCS at enrollment, and barn. A significant difference $(P \leq 0.05)$ was observed in the first 2 wk after calving.

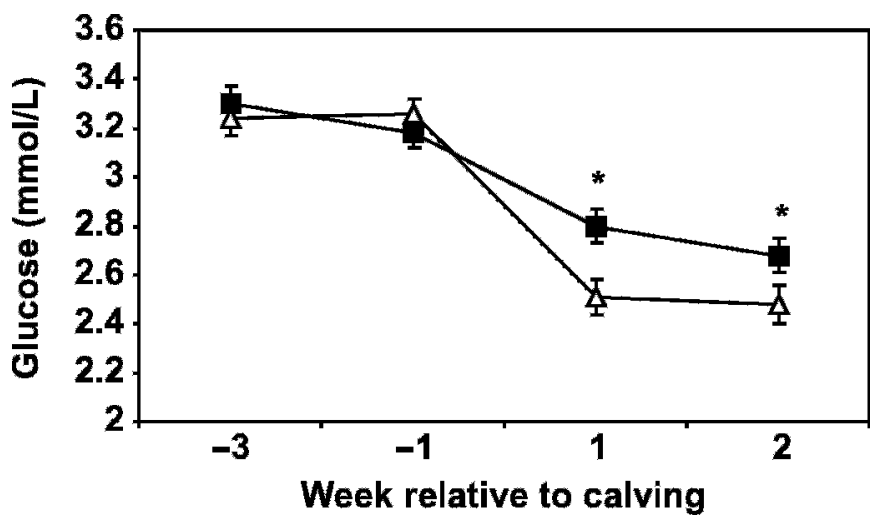

Figure 3. Least squares means ( $\pm \mathrm{SE})$ of serum glucose concentrations in animals receiving a monensin controlled-release capsule $(\mathrm{CRC}, \mathbf{\square})$ or not receiving a $\mathrm{CRC}(\triangle)$, adjusting for parity and calving season. A significant difference $(P \leq 0.05)$ was observed in the first 2 wk after calving.

of urea in comparison to animals that did not receive a CRC (4.11 vs. $4.33 \mathrm{mmol} / \mathrm{L}$, respectively, $P<0.05$ ).

$D M I$

Weekly DMI for each of the 4 treatment groups were analyzed. There was no interaction of the effects of RPC and CRC combined on DMI; therefore, the main effects of treatment were evaluated. Accounting for the significant effects of parity, BCS at enrollment, time (week relative to calving), barn, and season, there were no significant effects of either CRC or RPC supplementation on average DMI from 3 wk prepartum through 4 wk postpartum (all groups $12.6 \pm 0.1 \mathrm{~kg} / \mathrm{d}$ ), with no treatment by time interactions (Table 3 ). For descriptive purposes, the temporal changes in DMI

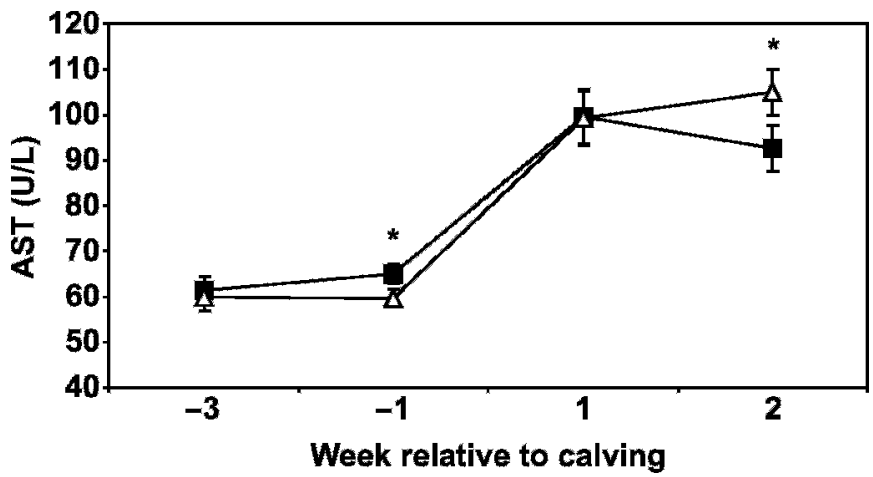

Figure 4. Least squares means $( \pm \mathrm{SE})$ of serum aspartate aminotransferase (AST) concentrations in animals receiving a monensin controlled-release capsule $(\mathrm{CRC}, \mathbf{})$ or not receiving a $\mathrm{CRC}(\triangle)$, adjusting for parity, BCS at enrollment, and barn. A significant difference $(P \leq 0.05)$ was observed in the first week before calving and the second week after calving. 
Table 3. Daily feed consumption from 3 wk before calving until 28 DIM, and milk production from calving to $60 \mathrm{DIM}^{1}$

\begin{tabular}{|c|c|c|c|c|c|c|c|c|c|c|}
\hline \multirow[b]{2}{*}{ Variable } & \multicolumn{10}{|c|}{ Treatment main effect } \\
\hline & $\mathrm{RPC}$ & $\begin{array}{l}\text { No } \\
\text { RPC }\end{array}$ & $\mathrm{SE}$ & $P$ & $\begin{array}{l}\mathrm{RPC} \times \text { fat } \\
\text { condition }\end{array}$ & CRC & $\begin{array}{l}\text { No } \\
\text { CRC }\end{array}$ & $\mathrm{SE}$ & $P$ & $\begin{array}{l}\mathrm{CRC} \times \text { fat } \\
\text { condition }\end{array}$ \\
\hline \multicolumn{11}{|l|}{$\mathrm{DMI},{ }^{2} \mathrm{~kg} / \mathrm{d}$} \\
\hline All & 12.5 & 12.2 & 0.15 & 0.20 & 0.02 & 12.2 & 12.5 & 0.21 & 0.20 & 0.03 \\
\hline $\mathrm{Wk}-3$ & 11.6 & 12.1 & 0.26 & - & - & 11.8 & 11.9 & 0.26 & - & - \\
\hline $\mathrm{Wk}-2$ & 11.3 & 11.4 & 0.25 & - & - & 11.4 & 11.4 & 0.25 & - & - \\
\hline $\mathrm{Wk}-1$ & 10.0 & 9.7 & 0.31 & - & - & 9.9 & 9.9 & 0.31 & - & - \\
\hline Wk 1 & 11.4 & 11.1 & 0.33 & - & - & 11.2 & 11.3 & 0.33 & - & - \\
\hline Wk 2 & 13.1 & 13.1 & 0.40 & - & - & 13.1 & 13.2 & 0.41 & - & - \\
\hline Wk 3 & 14.6 & 14.5 & 0.38 & - & - & 14.5 & 14.6 & 0.39 & - & - \\
\hline Wk 4 & 15.5 & 15.3 & 0.44 & - & - & 15.4 & 15.4 & 0.44 & - & - \\
\hline $\mathrm{BCS} \geq 4$ & 12.6 & 11.5 & 0.3 & 0.01 & - & 11.7 & 12.3 & 0.3 & 0.16 & - \\
\hline $\mathrm{BCS}<4$ & 12.7 & 12.9 & 0.2 & 0.26 & - & 12.9 & 12.7 & 0.2 & 0.28 & - \\
\hline \multicolumn{11}{|l|}{ Milk, ${ }^{3} \mathrm{~kg} / \mathrm{d}$} \\
\hline All & 32.0 & 30.8 & 0.3 & 0.02 & 0.001 & 31.5 & 31.3 & 0.3 & 0.88 & 0.001 \\
\hline $\mathrm{BCS} \geq 4$ & 31.4 & 27.0 & 1.0 & 0.001 & - & 28.5 & 29.9 & 1.0 & 0.26 & - \\
\hline $\mathrm{BCS}<4$ & 32.0 & 32.0 & 0.4 & 0.94 & - & 32.4 & 31.6 & 0.4 & 0.09 & - \\
\hline Milk fat, $\%^{4}$ & 4.04 & 4.02 & 0.07 & 0.80 & 0.54 & 4.01 & 4.06 & 0.06 & 0.62 & 0.34 \\
\hline Milk CP, $\%^{4}$ & 2.94 & 2.95 & 0.03 & 0.90 & 0.73 & 2.95 & 2.93 & 0.03 & 0.56 & 0.66 \\
\hline
\end{tabular}

${ }^{1}$ Holstein cattle received $56 \mathrm{~g} / \mathrm{d}$ rumen-protected choline (RPC) from 3 wk prepartum through 28 DIM, or a monensin controlled-release capsule (CRC) $3 \mathrm{wk}$ prepartum, in a factorial study design. There were no $\mathrm{RPC} \times \mathrm{CRC}$ interactions, nor treatment by time interactions. However, there were interactions of treatment with fat body condition (BCS $\geq 4$ ) at 3 wk before calving.

${ }^{2}$ Least squares means, accounting for the significant effects of parity, week relative to calving, season of calving, and barn.

${ }^{3}$ Least squares means, accounting for the significant effects of parity, week relative to calving, season of calving, BCS at $3 \mathrm{wk}$ before calving, and genetic index for milk production.

${ }^{4}$ Least squares means of the first 2 DHIA tests, which occurred at 21 and $50( \pm 10)$ DIM, accounting for the significant effects of DIM, season of calving, and BCS at 3 wk before calving.

over the study period are reported in Table 3. The mean prepartum DMI and postpartum DMI were 10.9 \pm 0.2 and $13.5 \pm 0.2 \mathrm{~kg} / \mathrm{d}$, respectively. However, there was a conditional effect of treatment on DMI among fat (BCS $\geq 4,3$ wk before calving) cows $(\mathrm{RPC} \times$ fat condition $P=0.02$; and $\mathrm{CRC} \times$ fat condition $P=0.03$ ). Among 131 nonfat cows with complete data, there was no effect of RPC $(P=0.26)$ or CRC $(P=0.28)$ on DMI across the experimental period $(12.8 \mathrm{~kg} / \mathrm{d})$. But among 39 fat cows, those that received $\mathrm{RPC}$ ate significantly more than those that did not receive RPC (12.6 vs. $11.5 \mathrm{~kg} / \mathrm{d}$ DMI, respectively), whereas DMI was not different among fat cows that did or did not receive CRC (11.7 and $12.3 \mathrm{~kg} / \mathrm{d}$, respectively, $P=0.16$ ).

\section{Milk Production and Components}

There was no interaction between RPC and CRC supplementation $(P=0.59)$; therefore, the separate main effects of treatment on milk production were analyzed. Accounting for the significant effects of parity, season of calving, BCS at enrollment, week postpartum, and genetic index for milk production, animals that received RPC supplementation throughout the transition period produced, on average, $1.2 \mathrm{~kg} / \mathrm{d}$ more milk through 60 DIM compared with animals that did not receive RPC supplementation (Table 3). However, the effect of RPC on milk production depended on BCS at enrollment $(\mathrm{RPC} \times$ fat condition (see above) interaction, $P=0.002$ ). Among 125 nonfat cows, there was no effect of RPC on milk production $(P=0.77)$. However, among 39 fat cows, those that received RPC produced $4.4 \mathrm{~kg} / \mathrm{d}$ more milk than those that did not receive $\mathrm{RPC}$ (Table 3). There was no effect of CRC administration on milk production (Table 3 ).

There was no interaction between DHI test number and treatment; therefore, milk fat and protein percentages were treated as a repeated measure for the first $2 \mathrm{DHI}$ tests. There was no RPC $\times \mathrm{CRC}$ interaction for milk components. Therefore, the main effects of the treatments were assessed. There were no significant effects of either RPC or CRC on milk fat or protein percentages for the first 2 DHIA tests (Table 3).

\section{Liver Biopsies}

A total of 127 liver samples was collected from 66 multiparous cows. Liver TG percentage and glycogen content at the first biopsy was offered as a covariate in the respective linear regression model for the second 


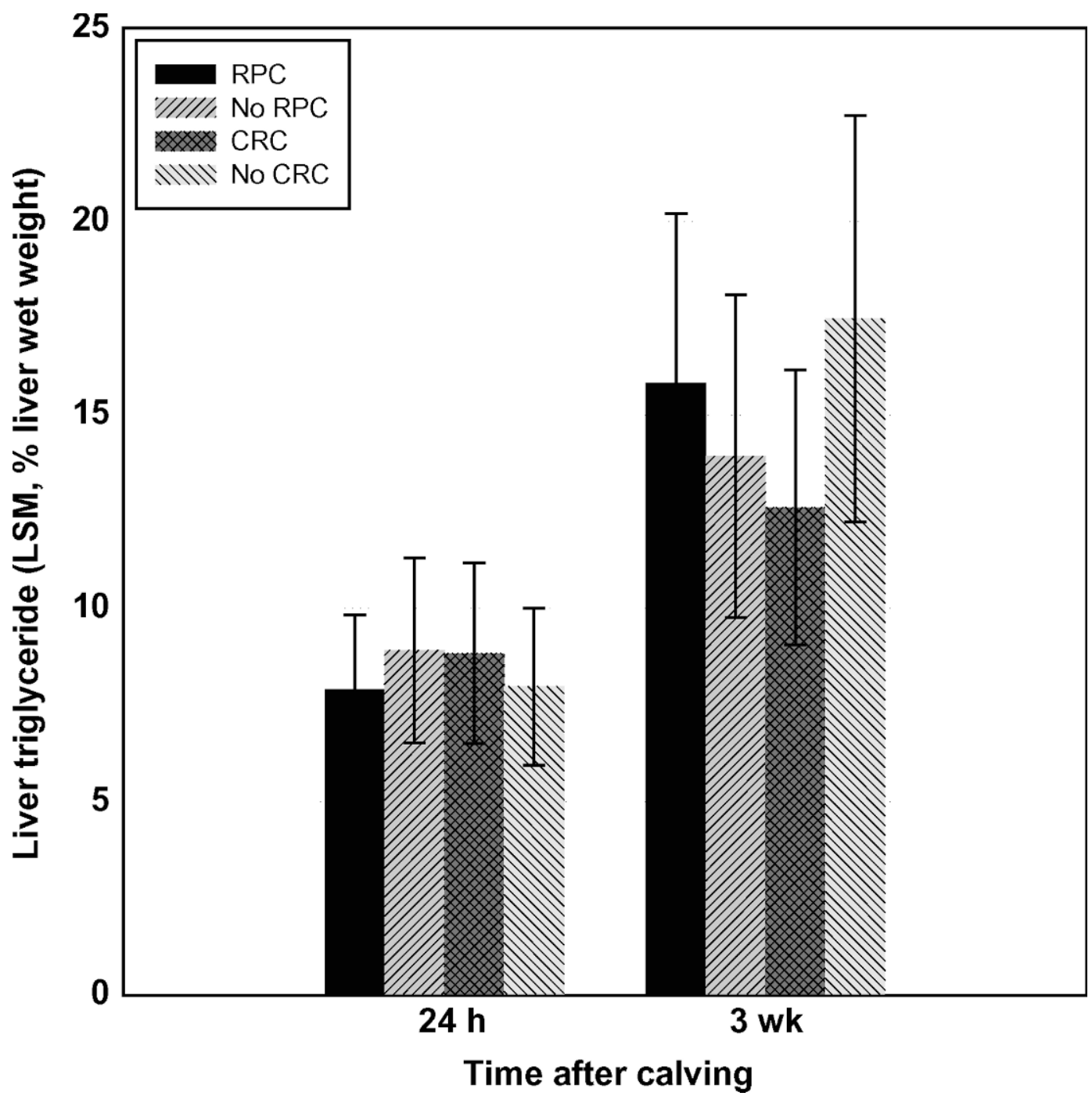

Figure 5. The effect of either rumen-protected choline (RPC) or monensin controlled-release capsule (CRC) on liver fat concentration in transition dairy cows; LSM $\pm \mathrm{SE}$, accounting for parity and BCS 3 wk before calving. There were no significant treatment effects.

biopsy, but was not associated with the results at the second biopsy. Because there was no significant interaction of the 2 treatments, the main effects of RPC and CRC treatment were evaluated. There were no significant effects of CRC or RPC on liver TG percentages at the first or second biopsy (Figure 5). Accounting for parity and BCS at $3 \mathrm{wk}$ before calving, there was a tendency $(P=0.12)$ for animals that received a CRC to have lower liver TG at $3 \mathrm{wk}$ into lactation, compared with animals that did not receive a CRC (Figure 5).

There was no significant effect of either treatment on liver glycogen content within $24 \mathrm{~h}$ after calving, but CRC significantly increased liver glycogen content at 3 wk postpartum (Figure 6 ). There were no interactions of treatment with BCS effects on TG or glycogen at either sample time.

\section{DISCUSSION}

\section{Metabolites}

There have been several studies on the effects of RPC or monensin independently on metabolism in dairy cattle. This is the first study in which the combined effects of RPC and monensin CRC on metabolic parameters have been studied.

In the present trial, supplementation of transition cows with RPC significantly decreased serum concentrations of cholesterol in the week before calving. In contrast, Pinotti et al. (2003) reported that supplementing transition dairy cows with $20 \mathrm{~g} / \mathrm{d}$ of RPC had no effect on serum cholesterol concentrations. The smaller sample size and the lower dose of RPC (12 g/ d) in Pinotti et al. (2003) may explain the difference. 


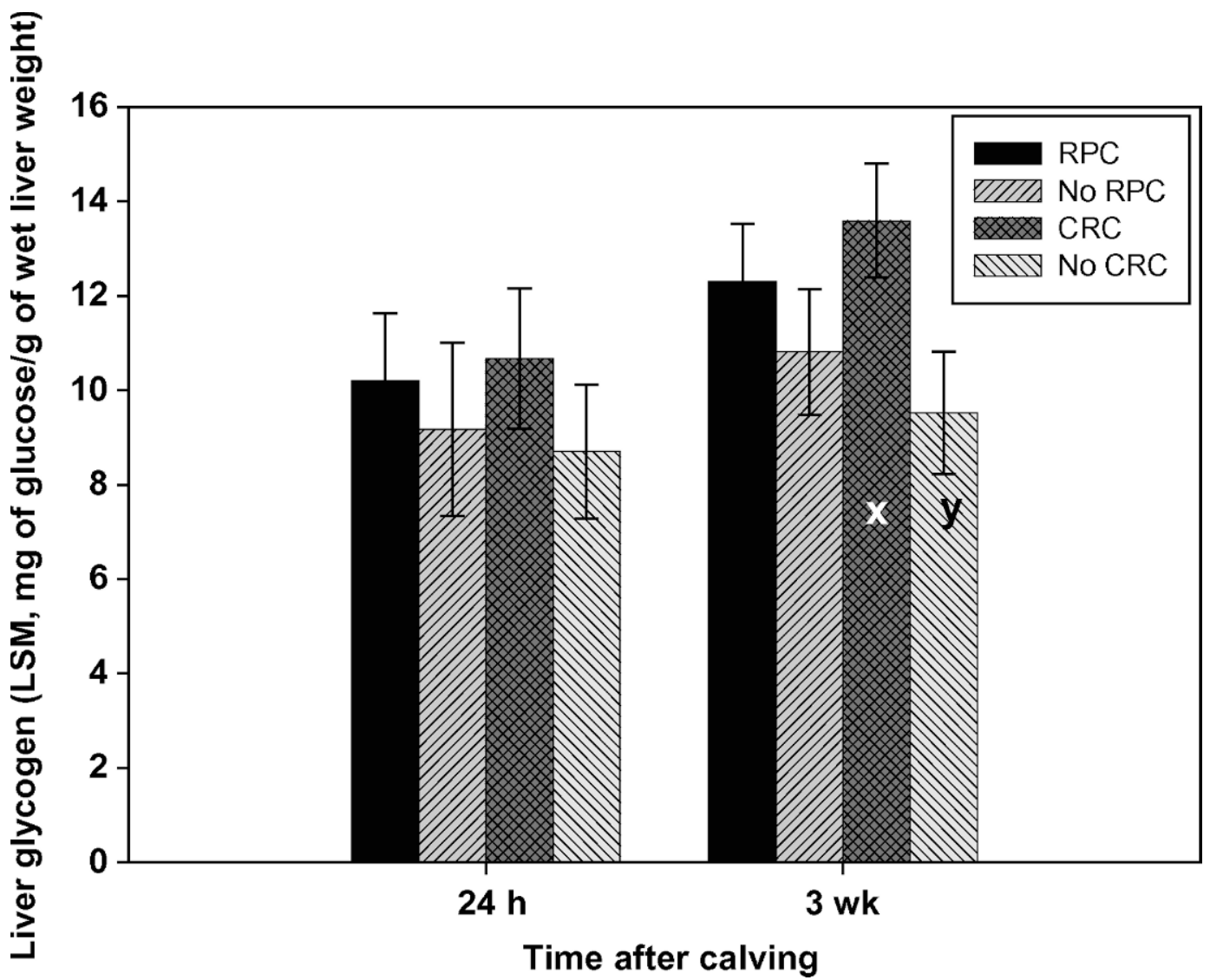

Figure 6. The effect of either rumen-protected choline (RPC) or monensin controlled-release capsule (CRC) on liver glycogen content in transition dairy cows; LSM $\pm \mathrm{SE}$, accounting for parity and season. Symbols $(\mathrm{x}, \mathrm{y})$ indicate a significant $(P=0.02)$ increase in liver glycogen content at $3 \mathrm{wk}$ postpartum in cows that received CRC.

Why RPC supplementation lowered serum cholesterol concentrations in the present study, and the biological significance of this change are unclear. Cholesterol is a component of the serum lipoproteins, and concentrations in serum give an indication of overall lipoprotein concentrations (Kaneene et al., 1997).

Administration of monensin CRC during the periparturient period significantly lowered the serum concentrations of BHBA in the first $2 \mathrm{wk}$ postcalving. This finding is in agreement with previous studies. Duffield et al. (1998a) reported that the administration of monensin CRC reduced serum concentrations of BHBA by 150 to $200 \mu \mathrm{mol} / \mathrm{L}$ in the first 3 wk postpartum. A smaller study (Duffield et al., 2003) reported similar results, whereby serum BHBA concentrations were significantly lower within the first week precalving and tended to be lower within the first week postcalving. Similarly, Green et al. (1999) reported a 35\% reduction in serum BHBA concentration in dairy cattle given a monensin CRC. In the present study, there was no significant treatment effect of supplementing dairy cattle with RPC on serum BHBA concentrations. This finding is supported by previous studies in which choline was either fed or infused to dairy cattle (Grummer et al., 1987; Piepenbrink and Overton, 2003; Janovick Guretzky et al., 2006).

In this trial, the significant lowering of serum BHBA concentrations in cattle that received CRC was coupled with increased serum glucose concentrations in the first and second weeks postpartum. This is in agreement with Duffield et al. (1998a) who also reported a significant increase in serum glucose concentrations during the first $2 \mathrm{wk}$ postpartum in cows that received a monensin CRC. However, a smaller study (Duffield et al., 2003) reported no significant effect on monensin CRC administration on postpartum glucose concentrations. Similarly, Hayes et al., (1996) reported no significant effect of monensin CRC administration on serum glucose concentrations in pasture-fed dairy cows. Pasture-fed dairy cattle tend to have lower milk production; therefore, it is possible that these animals 
did not experience the degree of negative energy balance associated with higher milk production.

Although CRC supplementation in the present study improved concentrations of the energy-associated serum metabolites BHBA and glucose, there was no effect of either RPC or CRC supplementation on serum NEFA concentrations. Similar to the current study, Abe et al. (1994) reported no effect of monensin CRC administration on serum NEFA concentrations. In contrast, both Duffield et al. (2003) and Stephenson et al. (1997) reported that administering monensin CRC to transition dairy cows significantly reduced serum NEFA concentrations in the week prior to calving. There have also been conflicting results with respect to the effects of RPC supplementation on serum NEFA concentrations. In agreement with the present study, several studies (Hartwell et al., 2000; Piepenbrink and Overton, 2003; Janovick Guretzky et al., 2006) reported no significant effects of RPC supplementation on serum NEFA concentrations. In contrast, Pinotti et al. (2003) reported that when cows were supplemented with $20 \mathrm{~g} / \mathrm{d}$ of RPC, serum concentrations of NEFA on the day of calving were significantly reduced. In the present study, blood samples were not obtained on the day of parturition; therefore, it is difficult to make a direct comparison with the study of Pinotti et al. (2003).

In this study, significantly higher serum urea concentrations were found when monensin CRC was administered. Previous work on monensin CRC has shown similar results (Duffield et al., 1998a; Hayes et al., 1996). It has been suggested that increases in serum urea concentrations associated with monensin CRC administration may be the result of the proteinsparing effect of monensin reducing the degradation of protein within the rumen, thus increasing its absorption in the small intestine (Hanson and Klopfenstein, 1979). Alternatively, blood urea levels may reflect liver function. Increased TG infiltration in hepatocytes can decrease the liver's ability to perform ureagenesis, thus lowering serum urea concentrations

In the current study, serum AST concentrations were significantly higher in the first week precalving and lower in the second week postcalving when cows were given a monensin CRC. Previous work by Duffield et al. (1998a) reported a significant decrease in AST concentrations when cows were administered monensin CRC; however, this was only in the postpartum period. The first $2 \mathrm{wk}$ postcalving is when liver function is likely to become impaired because of TG infiltration into hepatocytes; therefore, higher levels of AST postcalving may be indicative of reduced liver function (Kida, 2002). In the current study, it appears to be contradictory for animals that received monensin
CRC to have higher AST activity in the first week before parturition while also having significantly lower AST activity in the second week postpartum. The biological importance of these small differences is not clear.

\section{DMI}

In the present trial there was a conditional effect of supplementing transition dairy cows with RPC on DMI, such that fat cows that received RPC ate an average of $1.1 \mathrm{~kg} / \mathrm{d}$ more from 3 wk before calving through 4 wk after calving. This interaction was not reported in other studies, whereas the overall lack of effect is consistent with other reports. Erdman and Sharma (1991) indicated that supplementing early lactation cows with $0,15,30$, or $45 \mathrm{~g} / \mathrm{d}$ of RPC did not affect DM intakes. Similarly, Piepenbrink and Overton (2003) fed cows $0,45,60$, or $75 \mathrm{~g} / \mathrm{d}$ of RPC throughout the transition period and found no effect of RPC supplementation on DMI. Likewise, Pinotti et al. (2003) found no influence of choline supplementation on DMI when transition cows were fed $20 \mathrm{~g} / \mathrm{d}$ of RPC. It is generally accepted that an increase in DMI is correlated with an increase in milk production. In this study there was no significant association of RPC supplementation with metabolite indicators of health; therefore, it is unclear why fat cows supplemented with RPC had greater prepartum DMI. The lack of effect of monensin CRC on DMI is consistent with previous reports (Green et al., 1999; Fairfield, 2003). In the present study, despite detection of an interaction between CRC and fat BCS, there was no significant effect of monensin on DMI in fat or nonfat cows. Further study with a greater number of fat cows may be warranted. Many other studies on monensin CRC were large-scale field studies in commercial herds and did not measure DMI (Abe et al., 1994; Lean et al., 1994; Hayes et al., 1996; Duffield et al., 1998a,b).

\section{Milk Production}

In this study, RPC supplementation significantly improved milk production in the first $60 \mathrm{~d}$ of lactation, although RPC was fed from $21 \mathrm{~d}$ prepartum until 28 DIM. On average, RPC supplementation resulted in a significant increase in milk yield of $1.2 \mathrm{~kg} / \mathrm{d}$ compared with animals that did not receive RPC. However, the overall effect of RPC on milk production arose from its effect among fat cows. Pinotti et al. (2003) also reported a significant positive effect of RPC supplementation on milk production of $2.9 \mathrm{~kg} / \mathrm{d}$ for the first month of lactation. Similarly, Erdman and Sharma (1991) reported that RPC supplementation tended to 
increase milk yields in early lactation, while significantly improving milk production when supplemented in midlactation. However, the mechanism for this effect was unclear. In contrast, Piepenbrink and Overton (2003) reported no significant increase in milk yields when cows were supplemented with RPC. In the present study, the increase in milk production among fat cows appears to be attributable to increased feed consumption among this subset of animals. A mechanism of action for the observed effects was not evident in the other variables measured in this study.

There have been several studies in Canada and Australasia on the effect of supplementing transition cows with monensin on milk production. A large field study in Canada (Duffield et al., 1999) concluded that administering monensin CRC to transition cows conditionally increased early lactation milk yields in cows that had a BCS $\geq 4$. These fatter cows that received CRC produced $1.25 \mathrm{~kg} / \mathrm{d}$ more milk on average for the first 3 DHI tests compared with control cows. There were too few animals in the present study that were classified as thin or fat to make a similar comparison. In herds with a higher prevalence of ketosis, cows that received monensin CRC had significantly higher ++579 $\mathrm{kg}$ ) projected 305-d milk production compared with control cows (Duffield et al., 1999).

In the present study there was no effect of CRC or RPC supplementation on milk fat or protein percentage at the first 2 DHI tests. These results agree with Pinotti et al. (2003), Piepenbrink and Overton (2003), and Erdman and Sharma (1991) who also reported no significant effect of choline on milk components.

There has been conflicting evidence on the effect of monensin supplementation on milk fat and protein percentages. As in the present trial, Duffield et al. (1999) and Beckett et al. (1998) reported that monensin CRC supplementation did not affect milk components, whereas Phipps et al. (2000) found that increasing the dosage of monensin in the diet lowered milk fat and protein percentages. However, there are differences in diet, stage of lactation, dose of monensin, and duration of treatment among these studies.

\section{Liver Biopsies}

In the present study there were no effects of supplementing RPC on either liver TG percentage or liver glycogen content. Piepenbrink and Overton (2003) reported that when transition cows were supplemented with $0,45,60$, or $75 \mathrm{~g} / \mathrm{d}$ of RPC there was no difference in liver TG concentration, but there was a significant linear trend for increased liver glycogen content. Their results suggest a possible dose-response in the effect of dietary choline on liver metabolism. In a study with
6 to 7 cows per group (Hartwell et al., 2001), supplementation with $12 \mathrm{~g} / \mathrm{d}$ of choline in the periparturient period had no effect on gluconeogenesis.

This is the first study to examine the effect of the administration of monensin CRC on liver TG and glycogen contents. Monensin CRC significantly increased liver glycogen content at $3 \mathrm{wk}$ postpartum. In the present study, there was a tendency for cows that were administered a CRC to have lower liver TG percentages compared with controls at 3 wk of lactation. It has been suggested that excessive accumulation of triglycerides in the liver may contribute to an increased susceptibility to ketosis. This may be due to the impaired carbohydrate metabolism and thus decreased gluconeogenesis in cows with fatty liver, leading to ketogenesis (Drackley et al., 1992; Grummer, 1993). Monensin has been shown to decrease the incidence of subclinical ketosis in lactating dairy cows by $50 \%$ (Duffield et al., 1998a), which might be explained by the observed tendency for lowered liver TG and increased glycogen content in cows that received monensin in the current study.

\section{CONCLUSIONS}

The key finding of this study was that among cows entering the transition period in fat condition (BCS $\geq 4$ ), supplementation with RPC through the transition period resulted in increased milk production in the first 60 DIM, apparently attributable in part to improved feed intake. A metabolic basis for these effects, and why they were confined to fat cows, was not revealed by the present data. There were no significant interactions of the effects of supplementing both RPC and monensin CRC on blood metabolites, DMI, milk production, milk components, or liver function. Administration of RPC throughout the transition period increased milk production in the first $60 \mathrm{~d}$ of lactation, driven by its effect in fat cows, in which feed intake was improved. The present results indicate that an overall increase in milk production $(1.2 \mathrm{~kg} / \mathrm{d})$ may be observed with RPC supplementation in herds with over 1 in 5 cows in fat condition entering the transition period. The present results suggest that targeted supplementation of RPC to fat cows would likely result in a substantial $(4.4 \mathrm{~kg} / \mathrm{d})$ increase in milk production in early lactation. However, practically it may be difficult to deliver the supplement selectively in groupfeeding situations. Monensin CRC significantly reduced serum BHBA and AST concentrations, increased serum urea and glucose concentrations, and increased liver glycogen contents in the third week of lactation. There were no significant treatment effects on serum NEFA concentrations, or milk fat and pro- 
tein percentages at the first 2 DHI tests. Further research is needed to explore the mechanism of action of RPC and to quantify the circumstances under which RPC or CRC are profitable supplements.

\section{REFERENCES}

Abe, N., I. L. Lean, A. Rabiee, J. Porter, and C. Graham. 1994. Effects of sodium monensin on reproductive performance of dairy cattle. II. Effects on metabolites in plasma, resumption of ovarian cyclicity and oestrus in lactating cows. Aust. Vet. J. $71: 277-282$

Beckett, S., I. Lean, R. Dyson, W. Tranter, and L. Wade. 1998. Effects of monensin on the reproduction, health and milk production of dairy cows. J. Dairy Sci. 81:1563-1573.

Combs, G. F., Jr. 1992. The Vitamins in Fundamental Aspects in Nutrition and Health. Academic Press, Inc., San Diego, CA.

Cooke, R. R., R. R. Grummer, S. J. Bertics, D. Z. Caraviello, M. H. Ramos, and N. Silvia del Rio. 2004. Supplemental choline for prevention and alleviation of fatty liver. J. Dairy Sci. 87(Suppl. 1):343. (Abstr.)

Drackley, J. K., M. J. Richard, D. C. Beitz, and J. W. Young. 1992. Metabolic changes in dairy cows with ketonemia in response to feed restriction and dietary 1,3-butanediol. J. Dairy Sci. 75:1622-1634.

Duffield, T. F., and R. N. Bagg. 2000. Use of ionophores in lactating dairy cattle: A review. Can. Vet. J. 41:388-394.

Duffield, T. F., S. LeBlanc, R. Bagg, K. Leslie, J. Ten Hag, and P. Dick. 2003. Effect of a monensin controlled release capsule on metabolic parameters in transition dairy cows. J. Dairy Sci. 86:1171-1176.

Duffield, T. F., D. Sandals, K. E. Leslie, K. Lissemore, B. W. McBride, J. H. Lumsden, P. Dick, and R. Bagg. 1998a. Effect of prepartum administration of monensin in a controlled-release capsule on postpartum energy indicators in lactating dairy cows. J. Dairy Sci. 81:2354-2361.

Duffield, T. F., D. Sandals, K. E. Leslie, K. Lissemore, B. W. McBride, J. H. Lumsden, P. Dick, and R. Bagg. 1998b. Efficacy of monensin for the prevention of subclinical ketosis in lactating dairy cows. J. Dairy Sci. 81:2866-2873.

Duffield, T. F., D. Sandals, K. E. Leslie, K. Lissemore, B. W. McBride, J. H. Lumsden, P. Dick, and R. Bagg. 1999. Effect of prepartum administration of monensin in a controlled-release capsule on milk production and milk components in early lactation. J. Dairy Sci. 82:272-279.

Edmonson, A. J., I. J. Lean, L. D. Weaver, T. Farver, and G. Webster. 1989. A body condition scoring chart for Holstein dairy cows. J. Dairy Sci. 72:68-78.

Erdman, R. A., and B. K. Sharma. 1991. Effect of dietary rumenprotected choline in lactating dairy cows. J. Dairy Sci. $74: 1641-1647$.

Fairfield, A. M. 2003. The effects of monensin during the transitional period on rumen $\mathrm{pH}$ and indicators of cow health. MS Thesis, University of Guelph, ON, Canada.

Green, B. L., B. W. McBride, D. Sandals, K. E. Leslie, R. Bagg, and P. Dick. 1999. The impact of a monensin controlled-release capsule on subclinical ketosis in the transition dairy cow. J. Dairy Sci. 82:333-342.

Grummer, R. R. 1993. Etiology of lipid-related metabolic disorders in periparturient dairy cows. J. Dairy Sci. 76:3882-3896.

Grummer, R. R., L. E. Armentano, and M. S. Marcus. 1987. Lactation response to short-term abomasal infusion of choline, inositol, and soy lecithin. J. Dairy Sci. 70:2518-2524.

Hanson, T. L., and T. Klopfenstein. 1979. Monensin, protein source and protein levels for growing steers. J. Anim. Sci. 48:474-479.
Hara, A., and N. S. Radin. 1978. Lipid extraction of tissues with a low-toxicity solvent. Anal. Chem. 90:420-426.

Hartwell, J. R., M. J. Cecava, and S. S. Donkin. 2000. Impact of dietary rumen undegradable protein and rumen-protected choline on intake, peripartum liver triacylglyceride, plasma metabolites and milk production in transition dairy cows. J. Dairy Sci. 83:2907-2917.

Hartwell, J. R., M. J. Cecava, and S. S. Donkin. 2001. Rumen undegradable protein, rumen-protected choline and mRNA expression for enzymes in gluconeogenesis and ureagenesis in periparturient dairy cows. J. Dairy Sci. 84:490-497.

Hayes, D. P., D. U. Pfeiffer, and N. B. Williamson. 1996. Effect of intraruminal monensin capsules on reproductive performance and milk production of dairy cows fed pasture. J. Dairy Sci. 79:1000-1008.

Janovick Guretzky, N. A., D. B. Carlson, J. E. Garrett, and J. K. Drackley. 2006. Lipid metabolite profiles and milk production for Holstein and Jersey cows fed rumen-protected choline during the periparturient period. J. Dairy Sci. 89:188-200.

Kaneene, J. B., R. Miller, T. H. Herdt, and J. C. Gardiner. 1997. The association of serum nonesterified fatty acids and cholesterol, management and feeding practices with peripartum disease in dairy cows. Prev. Vet. Med. 31:59-72.

Kida, K. 2002. Use of every ten-day criteria for metabolic profile test after calving and dry off in dairy herds. J. Vet. Med. Sci. 64:1003-1010.

Kung, L., D. E. Putnam, and J. E. Garrett. 2003. Comparison of commercially available rumen-stable choline products. J. Dairy Sci. 86(Suppl. 1):275. (Abstr.)

Lean, I. J., M. Curtis, R. Dyson, and B. Lowe. 1994. Effects of sodium monensin on reproductive performance of dairy cattle. I. Effects on conception rates, calving-to-conception intervals, calving-toheat and milk production in dairy cows. Aust. Vet. J. 71:273-277.

Lo, S., J. C. Russell, and A. W. Taylor. 1970. Determination of glycogen in small tissue samples. J. Appl. Physiol. 28:234-236.

NRC. 2001. Pages 169-173 in Nutrient Requirements of Dairy Cattle. 7th rev. ed. Natl. Acad. Sci., Washington, DC.

Overton, T. R., and M. R. Waldron. 2004. Nutritional management of transition dairy cows: Strategies to optimize metabolic health. J. Dairy Sci. 87(E Suppl.):E105-E119.

Phipps, R. H., J. I. D. Wilkinson, L. J. Jonkers, M. Tarrant, A. K. Jones, and A. Hodge. 2000. Effect of monensin on milk production of Holstein-Friesian dairy cows. J. Dairy Sci. 83:2789-2794.

Pinotti, L., A. Baldi, I. Politis, R. Rebucci, L. Sangalli, and V. Dell'Orto. 2003. Rumen-protected choline administration to transition cows: Effect on milk production and vitamin E status. J. Vet. Med. A. 50:18-21.

Pinotti, L., A. Baldi, and V. Dell'Orto. 2002. Comparative mammalian choline metabolism with emphasis on the high-yielding dairy cow. Nutr. Res. Rev. 15:315-331.

Piepenbrink, M. S., and T. R. Overton. 2003. Liver metabolism and production of cows fed increasing amounts of rumen-protected choline during the periparturient period. J. Dairy Sci. 86:1722-1733.

SAS Institute. 1999. SAS User's Guide Statistics. Version 8, Developer's ed. SAS Inst., Inc., Cary, NC.

Sharma, B. K., and R. A. Erdman. 1988. Effects of high amounts of dietary choline supplementation on duodenal choline flow and production responses of dairy cows. J. Dairy Sci. 71:2670-2676.

Stephenson, K. A., I. J. Lean, M. L. Hyde, M. A. Curtis, J. K. Garvin, and L. B. Lowe. 1997. Effects of monensin on the metabolism of periparturient dairy cows. J. Dairy Sci. 80:830-837.

Veenhuizen, J. J., J. K. Drackley, M. J. Richard, T. P. Sanderson, L. D. Miller, and J. W. Young. 1991. Metabolic changes in blood and liver during development and early treatment of experimental fatty liver and ketosis in cows. J. Dairy Sci. 74:4238-4253. 